\title{
Feminisms on the web: lines and forms of action in contemporary feminist debate*
}

\section{Carolina Branco de Castro Ferreira**}

\begin{abstract}
The present article seeks to understand the uses of the internet as a space for action and reflection among feminist groups in the Brazilian scene. It takes as its focus the relationships between new feminist generations and esthetics and the social space of the internet. Several feminist groups have emphasized the use of the internet and social networks as relevant platforms for organization, news and political expression. I thus take as my object of analysis one of the most important blogs in the Brazilian context: Blogueiras Feministas (Feminist Bloggers - BF), seeking to use this as an ethnographic resource in order to understand the set of actors and collectives working within this feminist scenario, as well as the spaces and social, political and cultural strategies that appear within it.
\end{abstract}

Key Words: Feminism, Internet, Social Networks.

\footnotetext{
* Received February 23, 2015, approved 20, 2015. Translated by Thaddeus Blanchette. Reviewed by Richard Miskolci. I developed the text based on some points that I brought up during the opening of the Rethinking Gender and Feminisms seminar, held at Unicamp in September 2014 in order to commemorate the 20th anniversary of the Pagu Center on Gender Studies. The text also deals with questions that came up during my post-doctoral research in Barcelona, financed by Capes (Ferreira, 2013), and my current research, financed by Fapesp (Ferreira, 2014). I would like to thank Adriana Piscitelli, Iara Beleli and Richard Miskolci for dialogue, incentives and the trust that they have shown with regards to my theme. I would also like to thank Regina Facchini for our talks and for her suggestions with regards to the subject, as well as to Toret, who has accompanied my research with care, attention, patience and interest. Thanks also to Bibia Gregori, Isadora Lins França, José Miguel, Paula Togni, Natália Corazza, Laura Lowenkron and Bruno Barbosa.

** Doctor in Social Sciences at Unicamp. Post-doctoral researcher linked to the Pagu Gender Studies Nucleus at Unicamp, Campinas, SP, Brazil. carolinabcf.uni@gmail.com
} 
I don't have a garage, but

I have a room of my own and it's fully connected (Laura Bey). ${ }^{1}$

\section{Introduction}

In 1929, Virginia Woolf suggested that a room of one's own and an annual income were the necessary conditions for a woman to dedicate herself, autonomously and professionally, to writing. In this way, Woolf suggested that the space which traditionally neutralized women as producers of knowledge and culture - the home - be subverted. Zafra (2010) (re)appropriated Woolf's thoughts in order to contextualize them in today's internet culture. Here, a room of one's own is connected to the internet and, consequently, becomes transformed into a public-private online space. For this author, the "fully connected room of one's own" is a space configured as a private "operations center" for our online life. Zafra feels that such spaces create a highly versatile scenario that is full of potential and which can lead to the appearance of new opportunities with regards to the disciplinary systems of creative production and distribution. In this way, she sees the relationship between subjects, machines and online communication as a space for private concentration, excellently positioned as a contemporary territory for online experimentation (Zafra, 2011).

A room of one's own is part of a household and houses are traditionally feminized spaces, identified with women and with activities that are socially, culturally, and economically linked to the raising of families and children and the care of the old and ill (Zafra, 2010). For much of the past, domesticity, domestic labor and the private household were environments and activities that produced silences about themselves, systematically eliminating their own traces (Macclintok, 2010). Although the fully connected room of one's own is inserted into a household, it can be understood as a subversion of or an alterity within the home,

1 Mi vida en la primera IP, obra artística de 2010 apud Zafra (2011). 
especially when this is thought of as a dimension marked by hierarchical patriarchy (Zafra, 2010).

Looking at the fully connected room of one's own through the lens of its productivity, I would like to situate it as a space of experimentation. I wish to think about the conditions, effects, conflicts, possibilities and also the difficulties of creative feminist work within such a space and, in particular, in the context of its public-private online dimensions. Here, I am interested in looking at the efforts to specifically harness the internet as a locus for action and reflection by feminist groups. First I give an overview of some of the principle tendencies and points of debate related to the nexus of feminisms, technology and the internet. I then look at a blog that has been very active in the Brazilian scenario: Blogueiras Feministas (Feminist Blogger - BF). I use this as an ethnographic resource in order to better understand the set of agents and collectivities active within the Brazilian feminist blogosphere, as well and the political, cultural and social strategies at play there.

\section{Feminisms, technology and the internet}

Cyberfeminism began to appear in the 1990s. It might best be defined as a set of esthetic-political-communication strategies oriented towards electronic culture and, above all, the internet and digital technology (Boix and Miguel, 2013; Bañón, 2013; Bosch, s/a; Haché, Cruells and Bosch, 2013). This view of cyberfeminism is quite apparent in Donna Haraway's work, in the literary/cultural movement of cyberpunk and in many artistic and activist contexts then active on and around the internet. ${ }^{2}$ Several diverse groups ended up under this umbrella, including cyberfeminism, technofeminism, post-feminism, transfeminism, science fiction, post-porn and riot grrrl activism.

2 Regarding the debate about these influences and styles in the field of feminism, see: Zafra (2013, 2014); Preciado, 2007. In Brazil, see the dossier organized by Facchini and França (2011); Melo, 2013. 
The relationship between technology and feminism is older, however. In the 1970s, Firestone (1976) believed that the alliance between women and the development of reproductive technologies was a vector for ending the oppression of women, given that these technologies would liberate women from reproductive activities, which Firestone believed to be the basis of inequality between the sexes. ${ }^{3}$ In the 1980s, other activists called for greater participation of women in technological spaces as a means of combating the masculinized and stereotypical views of tech fields. These precursors of cyberfeminism saw technology as essentially neutral. Other tendencies, however, such as radical cultural feminism, eco-feminism (in both its essentialist and constructivism flavors) and socialist feminism promoted a certain technophobia (Bosch, s/a).

In the Euro-American scenes of the 1990s, the popularization of the internet promoted a practical and theoretical renewal in debates about feminism and technology (called by some the "third wave of feminism"). These were charged with optimism (often exaggerated $)^{4}$ with regards to women's participation in technology and, especially, the internet and were informed by the possibilities that new technologies offered for the transformation of gender. For the most part, however, this new field of debate also maintained a healthy skepticism with regards to the relationship between gender and technology. For example, VNS Matrix, an artistic collective founded in Australia and active between 1991-1997, produced installations, events and manifestos (the most famous of these

${ }_{3}$ Bosch (s/a); Piscitelli, 2008 (in-class comments).

4 A British example is Sadie Plant (1964 -), who associated cyberfeminism to the intimate and subversive relationship that women maintain with technologies. Her essay Zeros + Ones (1997) established relationships between binary code and the subversion of the binary logic inherent in sexual identity and the genetic code, postulating a post-gender world. Some years later, Plant re-evaluated her optimism as exaggerated, recognizing that, to a great degree, the liberating promise of technologies was open only to the "privileged". For thoughts regarding the political potential of Plant's work, in spite of her over-hasty optimism, see Zafra (2014). 
being the Cyberfeminist Manifest for the 21st Century ${ }^{5}$ ) which were distributed via internet. The collective is understood to be the first group of artists to use the term "cyberfeminism" and put it into practice. The group's focus was to produce sexualized and socially provoking relationships between women and technology using the medium of science fiction. Their works questioned discourses of domination and control in the expanding realm of cyberspace. Their DNA Sluts characters in the computer game All New Gen, for example, fought for "data liberation" against the G-Slime, using energy beams shot from their clitorises. The Sluts' objective was to incubate a "new world disorder" that questioned phallocentric logic.

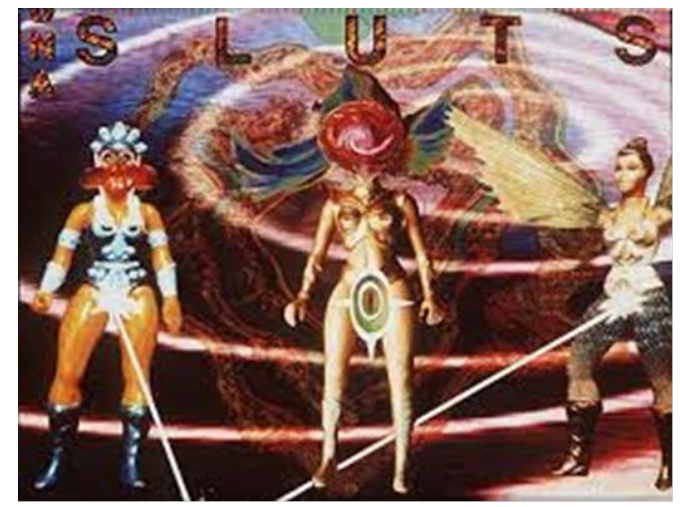

Figure 1: DNA SLUTS- digital image from a hypothetical computer game - Postcard by VNS Matrix (1996) http://www.maryjaneoverall.com

5 We are the modern cunt-positive anti-reason. Unbounded unleashed unforgiving. We see art with our cunt we make art with our cunt. We believe in jouissance madness holiness and poetry. We are the virus of the new world disorder. Rupturing the symbolic from within. Saboteurs of big daddy mainframe. The clitoris is a direct line to the matrix. VNS MATRIX: terminators of the moral codes. Mercenaries of slime go down on the altar of abjection probing the visceral temple. We speak in tongues infiltrating disrupting disseminating corrupting the discourse. We are the future cunt. 
Working through and around this political-artistic-esthetic scene, the first feminist actions on the internet made great and repeated use of repetitive action as a recursive strategy that sought to exhaust symbolic identities. In this context, for example, domesticity was represented through shifts and changes that promoted celebration, the decontextualization of bodies and excess. These actions also used technology as an object that questioned their own visual power, following Haraway (1995) who, while criticizing the logic-centered dimensions of visions of the non-corporeal, proposed redefining the act of seeing as a corporeal act. The new forms of colonizing images and linking them to technological power and the visual industries formed the basis for Haraway's visual metaphors, which sought to produce critical reflections regarding how to conceive of the subjects one knows, as well as of knowledge production, always understood within critical feminism as situated knowledge.

During this period, the relationship between feminisms, technology and the internet incorporated a political and esthetic discourse produced by the exchange of signs, cultural artifacts and deconstructions that were critical of norms linked to femininity. Some of the references in these iconographies and discourses can be found in science fiction, in cyborgs, in pornography and in sex with machines. Looking at the set of images that were circulating around the web at this time, there seems to have been a preponderance of themes originating in the "sex wars" and especially from the pro-sex feminism ${ }^{6}$ side of that debate. The category people of color appears mainly in those political practices and discourses that had a greater presence and representation in the field of the arts. This was the case of the Guerilla Girls, who criticized the absence of black and female artists in the New York gallery and exposition circuit. ${ }^{7}$ The Girls used gorilla masks as an

${ }^{6}$ Regarding the "feminist sex wars", see Preciado, 2007; Gregori, 2010.

7 With regards to the social conditions in which these discourses linking art, race and regimes of visibility appear, it is important to cite bell hooks and her 1995 book Art on my mind. In this text, the author deals with how race and class are linked in the visual politics of the art world. Another important writer in this 
icon to produce anonymity for the group in public interventions and to represent a given set of subjects and demands.

The heterogeneous groups that made up this movement generally shared a view of technology as a materialized social product; a nexus combining artifacts, people, organisms, meanings and knowledges. Technology and gender were seen as mutually constructive. Most of these groups also incorporated the feminist debate's "performative turn" from the 1980s on. This gave way to new interpretations and representations of gender and sexuality, both in esthetic and political spaces, as well as in the disputes and questionings related to feminisms' subjects.

In the relationships between feminism, technology and the internet, these groups relied upon the transformative potential of this nexus. They sought to appropriate new technologies horizontally, occupying new spaces (and the internet was understood to be the primary site for this) and deconstructing the fixed and unitary categories of gender binaries.

This field, which brought together theoretical interests and political practices, has grown immensely over the last twenty years, expanding and extrapolating the notion of cyberfeminism. ${ }^{8}$ With

context was Octavia E. Butler, a black science fiction author who combined elements of her life experiences with class and race inequalities in her works. I would like to thank Thaddeus Blanchette for his comments on styles and feminisms and his suggestion regarding Octavia E. Butler, as well as for his translation of the present text.

8 Some authors have continued with this theme (see Boix and Miguel, 2013; Boix, s/a; Bañón, 2013; Bosch, s/a; Haché, Cruells and Bosch, 2013), at least occasionally, producing a struggle over whether or not a distinction should be made between social and esthetic cyberfeminism. I argue that cyberfeminism can be situated as a phenomenon of a given period, as a certain style which marked the debates regarding feminism, technology and the internet. In Brazil, the themes of cyberfeminisms have parallels with the international discussions, although they are rarely labeled using this precise term. We can perhaps bring together themes that often appear under the cyberfeminist label or in cyberfeminist debates, such as female hackers, programmers, media lab operators, softwear developers and etc. In order to see the contents and themes that this debate promotes in a compilation of texts by Brazilian, Argentinean and Spanish authors, see Natansohn, 2013. 
the beginning of the new century, these analyses began to incorporate an intersectional view ${ }^{9}$ and have embraced new themes, such as the role of women in the history of computing and technology, indicators of digital inclusion and exclusion, and the uses of information and communications technology (ICT) in relation to the empowerment of women and their organizations.

Within these debates, several different authors have pointed out the "technological fracture of gender", which has resulted in a binary technological habitus that is both hierarchical and unfavorable to women (Natansohn, 2013). According to this view of things, in order to "measure" the "extent" of this fracture one has to pay attention to social markers of difference (gender, class, race, age and nationality) as related to literacy (formal, digital and in English - the lingua franca of the internet), ability and opportunity to access the internet, people's uses of technology and, finally, their positioning in the production, design and governance of digital technology.

According to Natansohn (2013), although women were late adopters of the internet in Europe and Latin America, the numbers of male and female users on these continents are now more or less balanced. Natansohn believes that in Latin America, women have a greater presence in terms of their use of social networks and telephone services and, based on 2009 census data from Brazil, she believes that the gap between men and women's access to the internet has decreased significantly in recent years. In 2009, 37.5\% of Brazilian women and $38 \%$ of Brazilian men had accessed the internet (IBGE, 2009 apud Natansohn 2013), a diference of only $0.5 \%$. Aside from this, the number of Brazilian women using the internet grew more than the number of Brazilian men and this growth is even more in women's favor in the population's older cohorts. The 2013 Pesquisa Nacional por Amostras de Domicílio

9 In the sense of the international debates in the feminist political field of the later half of the 1990s, which were marked by the emergence of categories that alude to a multiplicity of differentiations that are linked to gender and that permeate the social (Piscitelli, 2008). 
(National Household Sampleing Research - PNAD) shows that Brazil's internet-using population grew from $49.2 \%$ of the nation in 2012 to $50.1 \%$ in 2013 , with women making up $51.9 \%$ of this ${ }^{10}$ (IBGE, 2013).

If, on the one hand, there exists a definite structural gender disadvantage with regards to, say, women's participation as executives in high tech firms, when we turn to the uses of technology, things become more complex and we can see different sorts of women employing different socio-tech practices. ${ }^{11}$ In this sense, aside from thinking about what sorts of subjects use the internet, we also need to think about the subjects produced by theses uses. Taking up, once again, Zafra's notion of a fully connected room of one's own (2010), now inhabited by prosumers (those who produce themselves while they engage in an activity), we can establish a dialogue with feminist imaginings and "ways of doing", as well as with the production of identities in this context.

\section{"We are different parts of the country, with different life experiences. We are feminists" - Blogueiras Feministas}

Alvarez (2014) proposes a new conceptual language to rethink feminism's dynamics and changes in Brazil and Latin America, working with the notion of discursive fields of action rather than feminist movements. These fields would be more than

\footnotetext{
${ }^{10}$ Research conducted by Ibope Inteligência between July and december of 2014 in Brazil among people older than 16 indicates that women are $53 \%$ of the country's internaughts. Taking into consideration Brazil's Economic Classification Criteria (Critério de Classificação Econômica Brasil - CCEB), this research also shows that the country's internet active population is concentrated among the $\mathrm{B}$ and $\mathrm{C}$ classes.

[http:agenciaEstado//g1.globo.com/tecnologia/noticia/2015/02/mulheres-saomaioria-entre-usuarios-de-internet-no-brasil-diz-pesquisa.html].

${ }^{11}$ Much research has been done on this theme. For example, the search for sexual-affective and loving relationships (Beleli and Felicity, in the present publication), the search for same sex partners (Miskolci, 2014), uses of pornography (Parreiras, 2010; Shah, 2005), collective actions and social moviments (Castells, 2009; Toret et alii, 2013), and feminist activism (ACSURSegovias, s/a). I thank Toret for calling to my attention the term socio-tech.
} 
agglomerates of organizations which dedicate themselves to dealing with a given problem. This understanding allows us to widen the spectrum of shared interpretative questions and political-cultural concerns in this context.

In framing feminisms as discursive fields of action, Alvarez (2014) develops a narrative review of three moments in the history of contemporary feminism using this analytical approach. The first, set in the context of dictatorships of the 1970s, focuses on the creation of the feminist movement, then thought of in the singular. The second, during the period of democratization and the emergence of neoliberalism, consists of the pluralization of feminism and the birth of mainstream thinking regarding gender. Finally, the third moment (the sidestreaming of plural feminisms and the multiplication of feminist fields), extending forward from beginning of the $21^{\text {st }}$ century, is marked by a more horizontal flow of discourses, by plural and heterogeneous feminist practices, especially in terms of feminism's linkages with diverse sectors of civil society. This has resulted in a further multiplication of feminist fields.

It is in Alvarez's this third step, I argue, that the internet has enabled the establishment of networks which deepen contacts between already existing political and feminist groups. It has also created other communication networks through the appropriation of this prosumer activity as a tool of political action and a resource for identification.

One of the most important nodes of these networks in Brazil is Feminist Bloggers (Blogueiras Feministas), originally created as a mailing list in order to discuss policy issues related to women during the first round of the 2010 elections. ${ }^{12}$ During the same year,

\footnotetext{
${ }^{12}$ In the present article, I prioritize the rise and the role of Feminist Bloggers as a collective subject in the context of feminist political communication networks. I leave for another time a more thorough discussion of the subjects involved in the creation and current management of the blog, although I believe this topic to be extremely relevant.
} 
a Wordpress blog ${ }^{13}$ was created as a result of these discussions. This blog is collectively and collaboratively managed and it has produced, in a very short period of time, a network of information diffusion via emails, facebook, twitter, tumblr, youtube and google+. Although I will speak a bit about this expanded communications network, I will concentrate more on the blog in the present article, because this was the first feature created by Feminist Bloggers and it continues to be a nexus around which the association's collective identity is produced and maintained.

Although they have a multitude of uses, a blog can perhaps best be defined as a publishing tool that uses a common format. Blogs are made up of text that are published at the top of the page and which are frequently updated, posted on a regular basis and positioned in reverse chronological order. Blogs also typically provide lists of links to related and/or recommended content and space for readers to comment upon any post (Amaral, Recuero and Montardo, 2009).

The collaborative management of Feminist Bloggers consists of sending texts related to feminist and associated topics that have been edited and selected by a group, usually composed of women with a certain "reputation on the internet" ${ }^{14}$ There are also posts ${ }^{15}$ by invited authors and translations, generally of texts drawn from

\footnotetext{
${ }^{13}$ Wordpress is s web-content management system, with open-license code, which is often used to create blogs. For a long time Feminist Bloggers used this system. Curfrently, the blog has migrated to another platform, although it maintains the format, functioning and esthetics of a blog.

${ }^{14}$ Many of the women have their own blog, or are active on more than one, as well as working in or being activists in the field of communications in general. In the present article, I concentrate on the emergence of the practices of Feminist Bloggers as a collective subject. "Reputation", in this case, refers to how a given subject's presence is perceived on the internet, involving their assiduousness and their capacity to organize, manage, find and distribute content, as well as the size of their network of influence (i.e. the number of their followers, friends, or "likes") and their respect for the etiquette and conventions of online activities.

${ }^{15} \mathrm{~A}$ term commonly used to designate short, informative texts or essasys on blogs and social networks.
} 
the North American feminist blogosphere. ${ }^{16}$ According to the group's memory, the blog...

...exists because we want to live out, on the internet, the experience of being feminists. We want to write posts, call out manifestations of male sexism, tweet, make videos, publish photos, organize demonstrations in the streets and on the net, and, in general, spread the idea that much must change in the relationships between men and women. On the other hand, this all has to do with a constant reflection regarding our own lives, of how we confront our contradictions, of how we can construct relationships with more autonomy and liberty (Section taken from the blog on 05/09/2014, in the item "Nossa Memória", my emphases). ${ }^{17}$

Another part of the interactions that produce the blog is a very active e-mail discussion list that is open to people who publish or read texts on Feminist Bloggers. Diverse topics circulate on this list: the organization and distribution of texts on the blog, for example, or news about women's groups and events throughout the country. The list also acts as a discussion space and fulfills a didactic function for those people learning about feminist theories and spaces. This dynamic is characterized by long conversations in which subjects report on situations in their personal lives in which they "find themselves acting as feminists" or when they may have doubts about whether or not they are "acting like a male sexist." 18 Looking at the texts posted on the blog, as well as the mailing list, one can clearly see that the public profile of the blog's frequenters

\footnotetext{
16 "Blogosphere" is the collective term used to designate a nexus of blogs within a given community or social network. Many blogs are densely interconnected, with bloggers reading each others' publications and creating links between them, referring to each others'work or posting commentary on each others' blogs.

${ }^{17}$ [http://blogueirasfeministas.com/about/nossa-memoria/]

${ }^{18}$ It is also common for personal experiences with conjugal violence (mainly threats and stalking) to be posted on the list. These cases normally involve boyfriends and husbands and often the poster asks for help or for information regarding who they should turn to.
} 
is largely made up of young women who are in the university and who often identify with other political affiliations, such as Brazil's black and LGBT movements. ${ }^{19}$

Feminist bloggers and its distribution networks and interactions in the digital environment is thus a privileged field for investigating the questions related to the experiences of a new generation of feminism in Brazil. The Bloggers' activities tend to gravitate around strategies understood as relevant to more recent generations of feminists (Gonçalves, Freitas and Oliveira, 2013; Gonçalves and Pinto, 2011; Facchini and França, 2011) in which the internet has played a fundamental role in linking up networks of "physical persons" ${ }^{20}$, as a resource, language and form of knowledge transmission, and also as a means of articulating positive intergenerational relations (Gonçalves and Pinto, 2011). In this scenario, the internet serves as a means of translating terms, ideas and struggles, based upon the efficacy of this activity in and of itself without presuming that feminism needs to be a consequence of an already formed consciousness. The Bloggers' goal is to attract younger women to feminism and to clarify the use of certain concepts, themes and/or key terms.

On the Bloggers' web, these practices often occur in the context of collective blogging campaigns ${ }^{21}$ and in posts that deal

\footnotetext{
${ }^{19}$ The e-mail list acts as a resource for those who need help or support related to these academic trajectories - suggestions for feminist reading lists or help in forming study groups regarding feminist themes. Young women are also often interested in researching Bloggers as part of end-of-term research projects (TCC). Less often, the list receives requests for financial aid (open calls for contributions) to aid students who have entered into higher education via Brazil's affirmative action laws.

${ }^{20}$ I use this term to refer to the NGOs, universities, parties or state institutions that were important in opening up institutional space for feminisms in Brazil (Gonçalves and Pinto, 2011; Facchini, Daniliauskas and Pilon, 2013).

${ }^{21}$ Collective blogging is a communication strategy used by feminist politicalcommunication networks to give visibility to or "heat up" a debate on the "net regarding a given topic or theme. Normally, calls for publication and the definition of the theme for these campaigns happen well before the day chosen to put the campaign in action. Campaigns are coordinated and organized through
} 
with themes related to feminism in everyday life. In 2011, Bloggers published several texts on the "Papo de Homem"22 ("Man's Talk") site, and on the blog itself, using humorous pedagogic resources in order to attempt to demystify the naturalization of gender inequalities. Advice to sexist men wanting to surrender (Conselhos a um machista em Redenção) set out seven pieces of advice for men who didn't want to reproduce sexist behaviors. ${ }^{23}$ The article's author $^{24}$ also warned that "this text isn't a recipe or a model. There aren't any easy ways out of sexism or shortcuts to a better future, but at least we can travel along some roads together". According to the author, the seven fundamental points to be followed were:

1) Quit being defensive.

2) Accept that you are privileged and reject your privileges.

3) Stay vigilant.

different points in the network and do not exclusively occur within Blogueiras Feministas, but include the majority of the people and groups active in these conversations. The topics are varied: Trans- visibility Day (2014); Women and the 50th Anniversary of the 1964 Military Coup (2014); Lesbian and Bissexual Visibility Day (2013); 125 Years of the Abolition of Slavery (2013); Decrominalization and Legalization of Abortion (2012); Childhood, Consumerism and Sexism (2011); Myths about Feminism (2011), and many others.

${ }^{22}$ The Papo de Homem, ou $\mathrm{PdH}$, is directed towards Brazilian men. It was created in 2006 by publicity agent and expanded to include the creation of workshops and talks on masculinity and men's behaviors, generally given to private companies. According to Prado (2013), the site's public is generally composed of university-educated men between 21 and 34 who are also white and heterosexual.

${ }^{23}$ On Papo de Homem: <http://www.papodehomem.com.br/conselhos-a-ummachista-em-redencao/> $>$ and on Blogueiras Feministas $<$ http://blogueirasfeministas.com/2011/08/carta-a-um-machista-em-redencao/>

${ }^{24}$ The texts published on Blogueiras Feministas include a small auto-biography, sometimes accompanied by a photo. In the case of this post, the photo reveals the author as a young white woman with long orange-colored hair, aged 20-25. She represents herself in the following manner: "My roommate [original term is in English] says that even though I am a vegetarian, metalhead and a feminist, I'm a cool person. I studued physics and was a computer programmer in Porto Alegre. I left all that to move to São Paulo and try out life here. I don't know what to do with my life: I only know what to do with my vacation time." 
4) Avoid sexist jokes.

5) Don't label.

6) Think.

7) Observe and transform daily life.

The post received 54 comments from people identifying themselves as men or women, split between both sites. These involved debates regarding the body, physical strength, the equitable division of domestic tasks, violence, lack of knowledge regarding feminism, and whether one should or should not be feminist, among other topics.

The latest text published on the blog, in November 2014, on the occasion of that month's Slut Marches, is on how to become an "empowered woman" through participating in one of Brazil's many Slut March collectives ${ }^{25}$. The post relates a situation its author $^{26}$ encountered in real life involving a debate at her university regarding Brazil's political system. One of the people invited to speak at the debate was a federal deputy who commented upon the discontent of the Brazilian population with regards to politics. This man called the audience's attention to how "This begins with the name 'deputy' itself. Look what is right in the middle of the word ["puta", or whore]. That can't mean anything good". The blogger then commented, "He repeated his attempt at a 'joke'. I think it was because no one laughed".

The author then talks about her activities during the debate, particularly when she called the deputy's ${ }^{27}$ attention to his behavior, leading to that dignitary offering up a public apology. Going beyond this, however, the post emphasizes the changes the

\footnotetext{
25 [http://blogueirasfeministas.com/2014/11/sobre-empoderamento/].

26 The author identifies herself as a student of political science. "A card-carrying slut, a whore with an empowered heart."

27 "I grabbed the mike and introduced myself something like this: 'First of all, I'd like to say that being a WHOTE [puta] isn't something that defines your character. It's not wrong and it isn't a sin. In the same way that being a deputy isn't a sin. I say this because it is important that we make sure that what we say isn't full of prejudices, especially when these are directed against a minority that has already suffered much violence in our society'."
} 
author passed through after becoming active in a Slut March collective:

3 or 4 years ago, I would have probably noticed this and kept quiet, even though I was angry and cursing him in my thoughts. Cursing him a lot, actually. But three years ago, I began to be active in the Slut March and it's now 4 years that I have been aware of the movement. In the March, I learned that you can't keep silent and I learned to not be afraid of speaking out. I remember my friends/sisters telling and encouraging me:

- "Grab the megaphone and speak! Go on!"

- "You GO give the interview to the journalist".

- "You need to speak!"

... speak, speak, speak... empower yourself... and it worked!

Having said this, I want to use this moment to invite every woman who is interested to become part of the Slut March. Empower yourself and empower other women! It is important, extremely important, that we encourage our friends, daughters, cousins, mothers, aunts, grandmothers and etc. to speak! To speak, always. To never remain quiet! Come empower yourself at the March. I promise that we will do what they did to me: "Grab the megaphone and speak! You can do it!" The March isn't something that just happens once a year: it is a movement that empowers women and makes the March's cries resonate everywhere, all year long, throughout our daily lives. With each response we give, with each $\mathrm{NO}$ we say, every time we point out male sexism and every other kind of prejudice, we are saying what the March says. So the invitation stands, as does my testimony, my Love and my eternal thanks to this beautiful movement (From the post "Sobre empoderamento" 13/12/2014). 
The comments on this post were made by people who selfidentified as women. They congratulated the author and talked about family or personal situations in their own lives where they either shut themselves up or took a position they recognized as feminist.

Communications strategies that employ blogs are linked to the fact that these function as personal diaries and spaces of expression, as well as platforms for writing and divulging authors' reports on their experiences, feelings and thoughts. ${ }^{28}$ In this sense, Blogueiras Feministas can be understood as a cultural artifact ${ }^{29}$ (Shah, 2005) that appropriates certain technologies through the concrete social experiences of subjects that the artifact's repertoire. It can be characterized as mutable; a thing that generates selfreferences and narratives that are mutually defined, rather than produced according to a master linear narrative (Shah, 2005). In this way, feminist ideals and convictions are produced and propagated through these digital networks.

Following Amaral, Recuero and Montardo (2009), I believe that blogs are communication tools that should be analyzed via the social networks that are constructed through their commentaries and links, understood here as social interaction. Blogs can thus be understood as publication tools that posses social impact and which aid in the construction of social structures through communication exchange. When bloggers exchange links through comments, blogrolls and posts, these are frequently understood as conversation (Amaral, Recuero and Montardo, 2009:37).

\footnotetext{
${ }^{28} \mathrm{~A}$ certain consensus in the bibliography regarding blogs shows that one of the first appropriations, which rapidly took place following the increased popularity of blogging, was the use of blogs as personal diaries (see Amaral, Recuero and Montardo, 2009).

${ }^{29}$ According to Shah (2005), who studied the uses and appropriations of pornography blogs by Indian women, a "cultural artifact" can be defined as a living repertoire of shared meanings produced by a community of ideas.
} 

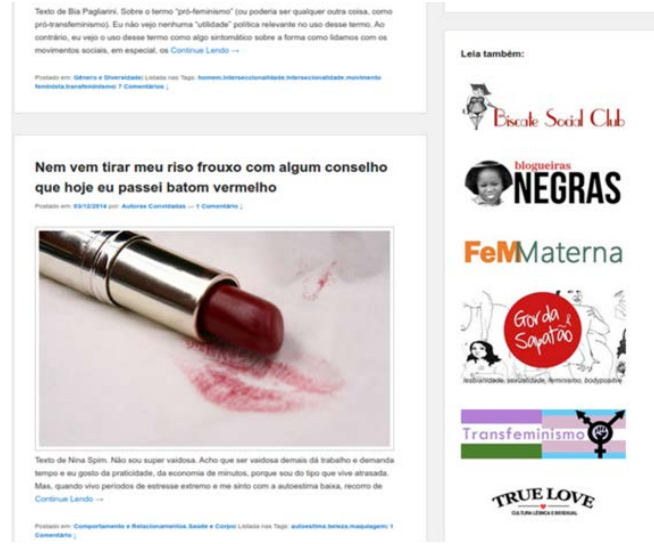

Figure 3: Conversations established with other blogs.

A look at the formal organization of the web and at the elements exposed on the page shows us quite clearly these feminist political-communicative networks (Alvarez, 2014). In this group, organizational practices are horizontal and multinodal, mixing community and technopolitical updates ${ }^{30}$ with transversal elements contributed by several different feminist groups. Figure 3, above, shows part of a conversation established via an indication for further reading in which appear other blogs such as Biscate Social Club, Blogueiras Negras, FeMaterna, Gorda e Sapatão, Transfeminismos and TruLove.

\footnotetext{
${ }^{30}$ Since the first decade of the 21st century, many collective actions have taken place in which communications technology have played a fundamental role (Castells, 2009; Toret et alli, 2013). The concept of technopolitics has been coined in order to understand this process. This refers to the tactical and strategic use of digital tools for collective organization, communication and action over the internet and which can originate on the internet, but are not necessarily limited to that environment. The concept of technopolitics has been much employed in order to better comprehend happening in the Arab world, especially in Egypt and Tunisia, the 15M experience in Spain (also known as "The Spanish Revolution" or the "Movement of the Indignant"), the Occupy movement in the United States (especially Occupy Wall Street) and the Yo Soy 132 movement in Mexico (Toret, et alii, 2013).
} 
Many authors who have looked at generational experience and intergenerational transmission in the field of Brazilian feminism have pointed out the importance of the university as a privileged locus for the feminisms that arose in the country between 1980 and 2000 (Gonçalves, Freitas and Oliveira, 2013; Gonçalves and Pinto, 2011; Facchini and França, 2011; Facchini, Daniliauskas and Pilon, 2013). Gonçalves (2014) emphasizes the need to understand how the theoretical knowledge produced by the universities has been received within the feminist movements.

According to Piscitelli (2008), international feminist debates of the 1990s were marked by the emergence of categories that allude to the multiplicity of axes of differentiation that, connected to gender, permeate sociability. According to this author, in the first decade of the 21st century, these categories are widely disseminated throughout several political fields in the world. However, as earlier occurred with the concept of gender, the categories began to take on different content following the interests and concerns of the authors who employed them.

The expansion and diffusion of categories of differentiation in the feminist debate can be thought of through the emic uses and notions that these categories have acquired in digital activist networks, revealing feminist appropriations of academic and theoretical discussions. The political-communicative networks that are inserted in Blogueiras Feministas reveal a mare's nest of interactions and discussions, established by groups and subjects that see themselves as "intersectional" and claim to be a part of "intersectional feminism".

By mapping out parts of these networks, we can see that not only are they influenced by the theoretical debate that Piscitelli mentions (2008), they also produce a notion of "intersectional" that gains its meanings through linking up various feminisms, other areas of struggle (the various trans-, black and differently-abled movements, for example) and the experiences of subjects who 
gain bodies and materialities in these scenarios. ${ }^{31}$ Being intersectional or practicing an intersectional feminism is produced here within this nest of linkages of and disputes over representations and meanings for and among oneself (Alvarez, 2014), using these notions to locate oneself in the growing mass of subjects who identify with the feminist field and with processes of decentralizing in the midst of these plural feminisms. ${ }^{32}$

Although these networks are strongly linked through the digital medium, they are not necessarily restricted to this environment. In the relational space between on- and off-line in which they operate, presences are created and a stable network of activism is being formed. The active moderating and updating of the blog on an almost daily basis leads to the Blogueiras being active in blog meetings and institutional-governamental events,

${ }^{31}$ Here, I refer to the solidarities that are produced, for example, between feminisms and the activism of the differently-abled (Ferreira, 2013; Ferreira 2014) or black feminism, as Alvarez has discussed (2014), something which is in and of itself a wide and diverse field for discursive action.

${ }^{32}$ How the theme of intersectionalities is appropriated, what its meanings are and what alliances and solidarities are generated around and through it have are questions that have attracted my attention in my attempt to understand how these discursive communities organize themselves. My initial mapping of these networks has revealed that they operate through agents who consider themselves to be "intersectional" and/or "radical". One of the characteristics of the activities of the "intersectional" side of these agents is their attempts to link to other groups and struggles, as I mentioned above. The "radicals", however, advocate for a certain centrality of the relationship between the body and power, whereby "having a vagina" is a determining factor. The presence of these "radicals" in these digital networks seems to have come after that of the "intersectionals", emerging principally in 2013 and later. These "communities" do not operate in a completely dual fashion, of course. There are subjects (and here I am thinking of blogs, Facebook profiles and etc.) that shift between both poles, now radical, now intersectional, depending upon the theme at hand. The reflections presented here are quite preliminary and there is no space to fully develop them in the current article. I do have a good ethnographic example of this problem, however, which involves the slut march, the presence of transwomen and the meanings and uses of violence (see http://blogueirasfeministas.com/2014/09/marcha-das-vadias-desalvador-contra-a-transfobia/). I would like to thank Regina Facchini for having called my attention to this polarity between "intersectionals" and "radicals". 
producing channels of intergenerational transmission within the various feminisms, given that feminist militancies are subject to different generational experiences. ${ }^{33}$

In 2006, Sonia Corrêa and Adriana Vianna debated the movements of subjects, strategies and demands regarding sexual rights within the Brazilian scenario. Vianna (2006) mentioned some of the inevitable tensions in feminist interactions with other actors, given that other axes of the production of inequality and domination have appeared that are not locked into the binary and naturalized logic of the masculine/feminine dyad. In these spaces, color/race/ethnicity comes into play, as does sexual preference and even esthetics. Vianna believes that there is an essentialist appeal associated with a certain kind of reading of domination. She calls this the victory of "those who love don't kill" over "our bodies belong to us": a victory, in other words, for victimization and suffering as feminist strategies. ${ }^{34}$

If the production of conventions and the politicization of public spaces invariably involves esthetics, it is also true that politics produces esthetics through its slogans, its material culture and through the ways it connects practices with individual and collective experiences. In this sense, I argue that the politicalcommunicative networks that originate in digital networks are important elements for understanding and investigating this current opposition between the "those who love don't kill" side of feminism and the "our bodies belong to us" side. These two trends have produced and modified certain styles of production of feminist conventions, which can be thought of in terms of their moral and esthetic dimensions of interaction, as well as their impact and reach.

${ }^{33}$ Blogueiras Feministas participated in the III Conferência Nacional de Políticas para Mulheres, 2011 (III National Conference for Women's Policy), the $2^{\circ}$ Conferência Nacional de Políticas Públicas e Direitos Humanos de LGBT, 2011 (2nd Conference for LGBT Public Policy and Human Rights), and the $13^{\circ}$ Encontro Feminista Latinoamericano e do Caribe, 2014 (13th Latin American and Carribean Feminist Encounter).

${ }^{34}$ I would like to thank Laura Lorewkron for calling my attention to this debate. 
These "ways of doing feminism" in digital networks are linked to mass self-communication (Castells, 2014) ${ }^{35}$, whose contemporary form, which establishes communication processes linked to the use of communication technologies and sociotechnical apparatuses, permits the expansion and linkage of emotional states which coordinate collective action, but which also elaborate demands for recognition through the affective, social and moral mappings undertaken by the subjects involved. ${ }^{36}$ This dynamic applies to the range of interpretive questions, concerns and political-cultural conflicts within the feminist scenario. At its limits, it produces those who are "rejected by feminism", but who insist on proclaiming themselves to be feminists and who are also linked to this discursive field (Alvarez, 2014; Ferreira, 2014a). ${ }^{37}$ Here, one can think of the disputes within feminism as different utopian and normative projects, currently linked to the discussions regarding being pro-feminist or feminist in contexts where cis-

\footnotetext{
35 "In the last few years, a fundamental change has occurred in the domain of communication, which I call self-communication - the use of the internet and wireless networks as a platform for digital communication. It is mass communication because it processes messages by the many, for the many. It has the potential to reach a large and diverse audience and connect with a boundless number of networks that transmit digital information to the neighborhood or to the world. It is self-communication because the production of messages is decided in an autonomous fashion by the producer herself. The audience is selfdesignated and recovering messages from the communication network is a selfselected process. This form of mass communication is based on horizontal networks of interactive communication that generally are difficult for governments or companies to control. Aside from this, digital communication is multi-modal and permits constant reference to a globalized hypertext whose components can be remixed by the communicative actor according to specific communication projects." (Castells, 2014:15).

${ }^{36}$ The inspiration for this argument comes from Vianna (2012).

${ }^{37}$ Also connected to this discursive field are those who have established a negative reciprocity with feminism. This is the case of the "Women against feminism" ("Mulheres contra o Feminismo") movement, with their slogan "We owe nothing to feminism" and the various Men's Rights and Masculinist groups, which have recently begun to have a presence on the Brazilian internet, following the popularization of these discourses in the North America gender-issues blogosphere.
} 
and/or trans- men are present. The dynamic of those who are "rejected by feminism" has also been to create accusatory categories that can be employed as a resource for differentiation and innovation, as well as a form of humor within these discursive fields of action. ${ }^{38}$

Alvarez (2014) calls attention to the complex formation of today's feminist politics and its drive to "return to the streets", which has moved it to remodel itself through interactions with what has begun to be called "the June demos". ${ }^{39}$ The interactions of these feminist political communicative networks with the mass demonstrations of June 2013 in Brazil are doubtless extremely relevant. ${ }^{40}$ I believe, however, that this "return to the streets" has

\footnotetext{
${ }^{38}$ As an example, take the debate in the U.S. regarding the term bad feminist, coined by Roxane Gay, an activist born in Haiti whose book of the same name advocates for "a more flexible activism" and an "imperfect feminism". The term also permeated the debates regarding Beyoncé's participation in the 2014 Video Music Awards. The singer put Nigerian activist Chimanda Ngozi Adichie's words to music and declared herself to be feminist as part of her performance. These North American references are present in Brazilian debates, principally in the conversations carried out on and between blogs and in debates regarding the construction of a "inclusive feminism". In Brazil, the pejorative term "cute feminism" is used as an accusation against those views that are seen as affirming the belief that women need to please men in order to be heard and that if women act as "classic feminists" they will not be listened to. Another term "feminismo deboista" ("calming feminism") has also been produced by a Facebook fan page as a humorous term used to try to reduce conflicts between feminist groups.

${ }^{39}$ Regarding the "June demos", see Gohn, 2014 ; Ortellato, 2013; Moraes et. alli, 2014.

${ }^{40}$ Regarding the importance of this political-communicative feminist network during the June 2013 demonstrations, see Fábio Malini's (Laboratório de Estudos sobre Imagem e Cibercultura - LABIC, Universidade Federal do Espírito Santo UFES) image of the network of Facebook fan pages that took significant actions during the demonstrations. This map shows the fan pages which each of these channels "liked". These fan pages are a message-transmitting/emitting nucleus on Facebook and the individual profiles linked to these pages are "the cells through which these messages echo" (Malini, 2014). The light pink "cloud" below the map represents the feminist political-communication networks [http://www.labic.net/grafo/a-nova-grande-midia-a-ecologia-midialivristabrasileira-no-facebook/].
} 
been ongoing since 2011, at least, when the internet mobilizations coordinated (principally through Facebook, Twitter and several blogs) to occupy public space consolidated in annual political events against gender-based violence, the explosion of the various Slut Marches in Brazil being a prime example of this. I believe that the Slut March has been one of the most important actions to occur in the last five years within this scenario. It originated within the linkages between digital networks and the occupation of public spaces and it also created relevant nexuses within the politicalcommunication network analyzed in the present article. ${ }^{41}$

One point that stands out in the ethnographic situations described above is the importance Slut March has taken on as a pedagogic space in which these political-communicative networks are recognized. Ferreira (2013a) analyzed the imagery related to this event which circulated on the internet. This was composed of photos taken at the event, as well as images created by the various campaigns launched by these collectives on Facebook. According to the author, the most outstanding images show bodies being used as creative instruments of political protest, creating strategies that defied public taboos regarding nudity and the public exposition of certain types of bodies, all a part of expressing the ideas proposed by the mobilization. These photographic campaigns re-appropriated some of feminism's historical platforms (the right to pleasure, the fight against esthetic oppression, equal pay for equal labor, equality in the moral patterns linked to sexuality) and connected these to the day-to-day lives of many different population segments (women of all ages, men, children).

I believe that the several Marches that have been occurring in Brazil since 2011 (as part of the political-communicative networks that have the internet as their locus) have opened up a space for reconnecting feminist conventions related to both the

\footnotetext{
${ }^{41}$ As a methodological decision (and given that space is limited in an article), I have decided to deal with the Slut Marches through the narratives presented on Blogueiras Feministas. On an earlier occasion, I reflected upon the origins of the Slut Walk in North America and the explosion of the Slut Marches / Marcha das Vadias in Brazil (Ferreira, 2011).
} 
"those who love do not kill" and the "our bodies belong to us" factions. In the first instance, the activities of the feminist collectives on the digital networks widened the semantic and grammatical politics that refer to notions of violence, questioning processes of recognition and denunciation. Notions such as violence during pregnancy and labor came up, digital harassment and revenge porn came up in this context. ${ }^{42}$

In the second instance, that of "our bodies belong to us", spaces were opened up in the Slut Marches to talk about bodies and embodiment. Here we saw discussions about languages and strategies that could be used to de-stigmatize the public appearance of female nudity and promote that decriminalization of abortion. We also saw debates regarding trans- bodies and radical discussion of patterns of beauty, from which have emerged recent anti-oppressive concepts, such as "fatphobia" and "ableism", indicative of a series of criticisms regarding the body's supposedly "normal condition".

\section{Final considerations}

Throughout the present article, I have tried to understand the uses of the internet and the online environment as a locus for reflection and action by feminist groups. In order to do this, I have resumed some of the tendencies and debates that permeate feminisms, technology and the internet. I also utilized the concept

\footnotetext{
42 Revenge porn is posting pornographic photos of one's ex-partner without their permission after the end of a relationship. The use of the word "puta"/vadia" (whore or slut) also appears as a polemical debate in these politicalcommunicative networks. The Marches' general opinion is that the word is being re-appropriated from its pejorative sense, in which it is used to regulate female sexuality, and transformed into a mark of solidarity. In order to better see how feminist conventions are being reworked in the proposals of the Marcha das Vadias collectives, see Tavares (2014). The general view seems to be that one needs to attack stigma head on in order to combat violence against women: in particular the stigmas to which sex workers and sex work are subject. For a more general analysis that focuses on the positions of young feminists in Brazil with regards to prostitution, see Piscitelli (2014).
} 
of "a fully connected room of one's own", linked to the material produced by the Feminist Bloggers, to think about the production of collective subjects and feminist digital networks in Brazil. Though this context has produced new and creative resources, it has also created difficulties.

These political-communication networks originating on the 'net are important elements in understanding and investigating conventions linked to violence and corporalities in today's feminist scene. The activities of feminist collectives on the internet have widened semantic and grammatical politics with regards to notions of violence. What elements of victimization and suffering have appeared and how? What are their complexities? How have digital media been used to do what has been called "victim conscientization"? These networks have also created languages in order to direct the public appearance of bodies. What bodies and what social marks are shown? In what spaces? What solidarities in this field are difficult to create, even though they might be greatly desired?

Zafra's re-appropriation of Woolf's "room of one's own", this time connected to the digital sphere, permits us to see that the conditions for female autonomy have changed. In principle, the position of the connected room of one's own seems to equally serve all. However, it is in the interaction of different social markers of difference that it becomes possible to see which subjects and lines of praxis have more intensively used the internet in their strategies.

Looking at the material posted on Feminist Bloggers allows us to see that both the women who produce it as well as read it are young and often in their first approach towards feminism. They are also largely university students in a country whose student population, in recent years has been reconfigured in terms of class, age and region, due to new social policies regarding education. This context frames the "simultaneity of the multiplication of popular feminisms and the popularization of feminisms" (Alvarez, 2014), in which these digital networks are inserted in the 
production of feminist ideals linked to urban life and centered in some of Brazil's principal metropolises.

\section{Bibliography}

Alvarez, Sonia E. Para além da sociedade civil: reflexões sobre o campo feminista. cadernos pagu (43), Campinas-SP, Núcleo de Estudos de Gênero - Pagu/Unicamp, 2014, pp.13-56.

Amaral, Adriana; ReCUero, Raquel; MontARdo, Sandra. Blogs.com: estudo de blogs e comunicação. São Paulo, Momento Editorial, 2009 [http://www.sobreblogs.com.br - acesso em agosto de 2014].

BoIX, Montserrat; Miguel, Ana de. Os gêneros da rede: os ciberfeminismos. In: NATANSHON, Graciela. Internet em Código Feminino: Teorias e Práticas. Buenos Aires, La Crujía Ediciones, 2013, pp.39-76 [http://www.genderit.org/sites/default/upload/livrogiga_internet_cod_fe m_ptbr.pdf - acesso em agosto de 2014].

BosCH, Nuria Vérges. Teorias Feministas e Pós-Feministas de las tecnologias. Kit de Formación: género, Tic y activismo, ACSUR-Las Segovias s/a [http://www.x0y1.net/KIT_CAST_6-1.pdf - acesso em agosto de 2014].

BAÑón, Sonia Reverter. Ciberfeminismo de virtual a político. Revista Teknocultura,vol. $\quad 10, \quad \mathrm{n}^{\circ} 2, \quad 2013, \quad$ pp.451-461 [http://teknokultura.net/index.php/tk/article/view/159 - acesso em agosto de 2014].

CASTEllS, Manuel. Redes de Indignação e Esperança: movimentos sociais na era da internet. Zahar, 2014.

. Comunicación y poder. Madrid, Alianza Editorial, 2009.

FACCHINI, Regina; FRANÇA, Isadora Lins. Dossiê Feminismos Jovens. cadernos pagu (36), Campinas-SP, Núcleo de Estudos de Gênero Pagu/Unicamp, 2011, pp.9-24.

FerReIRA, Carolina Branco de Castro. Produção de corpos e cuidados: deficiências, erotismos e mercado do sexo. Fundação de Amparo a Pesquisa de São Paulo -FAPESP - Projeto de Pesquisa de PósDoutorado, 2014. 
. Mulheres x feminismo.Folha de S. Paulo, Folha equilibrio, 2014a [http://www1.folha.uol.com.br/fsp/equilibrio/186994-mulheresxfeminismo.shtml\# - acesso em fevereiro de 2015].

.Yes, we fuck": sexualidade, "diversidade funcional" $e$ mercado do sexo. V Congresso da Associação Portuguesa de Antropologia, Vila Real, 2013 [https://www.academia.edu/6922944/].

.A Força das Vadias. Global Brasil,n ${ }^{\circ}$ 14, Rio de Janeiro, 2011, [http://www.revistaglobalbrasil.com.br].

FERREIRA, Gleidiane de S. Feminismo e redes sociais na Marcha das Vadias no Brasil. Revista Ártemis, vol. XV, nº 1, jan-jul, 2013, pp.33-43.

FIRESTONE, Shulamith. A dialética do sexo: um estudo da revolução feminista. Rio de Janeiro, Editora Labor do Brasil, 1976.

HaCHÉ, Alex, CRuells, Eva; BosCH, Nuria Vérges. Eu programo, tu programas, elx hackea: mulheres hackers e perspectivas tecnopolíticas. In: NATANSHON, Graciela. (org.) Internet em Código Feminino: Teorias e Práticas. Buenos Aires, La Crujía Ediciones, 2013, pp.77-96 [http://www.genderit.org/sites/default/upload/livrogiga_internet_cod_fe m_ptbr.pdf - acesso em janeiro de 2015].

GoHN, Maria Glória. Manifestações de Junho de 2013 no Brasil e praças dos indignados no mundo. São Paulo, Editora Vozes, 2014.

HARAWAY, Donna. Saberes Localizados: a questão da ciência para o feminismo e o privilégio da perspectiva parcial. cadernos pagu (5), Núcleo de Estudos de Gênero - Pagu/Unicamp, 1995.

IBGE, Instituto Brasileiro de Geografia e Estatística. Síntese de Indicadores Sociais: uma análise das condições de vida da população brasileira, 2014

[ftp://ftp.ibge.gov.br/Indicadores_Sociais/Sintese de Indicadores_Soci ais_2014/SIS_2014.pdf - acesso em janeiro de 2015].

MALINI, Fábio. A nova Grande Mídia: a ecologia midialivrista brasileira no Facebook, 2014 [http://www.labic.net/grafo/a-nova-grande-midiaa-ecologia-midialivrista-brasileira-no-facebook/ - acesso em fevereiro de 2015].

MCCLINTOCK, Anne. Couro Imperial: Raça, Gênero e Sexualidade no Embate Colonial. Campinas-SP, Editora da Unicamp, 2010. 
MELO, Érika Isabel de. O Feminismo não morreu - as riot girrrsl em São Paulo. Revista Ártemis,vol. XV, no 1, jan-julho 2013, pp.161-178 [http://periodicos.ufpb.br/ojs/index.php/artemis/issue/view/1259/show Toc - acesso em janeiro de 2015].

MISKOLCI, Richard. San Francisco e a nova economia do desejo. Lua Nova (91), São Paulo, 2014, pp.269-295

MoraEs, Alana; GutierréZ, Bernardo; PARRA, Henrique; AlbuQUERQUE, Hugo; TIBLE, Jean; SHAVELZON, Salvador. (orgs.)Junho potência nas ruas e nas redes. São Paulo, Fundação Friedrich Ebert, 2014 [http://library.fes.de/pdf-files/bueros/brasilien/11177-20150226.pdf acesso em janeiro de 2015].

NATANSHON, Graciela. O que tem haver as tecnologias digitais com gênero? In: NATANSHON, Graciela. (org.) Internet em Código Feminino: Teorias e Práticas. Buenos Aires, La Crujía Ediciones, 2013, pp.15-38

[http://www.genderit.org/sites/default/upload/livrogiga_internet_cod_fe m_ptbr.pdf - acesso em janeiro de 2015].

ORTELLATO, Pablo. Os protestos de junnho entre o processo e o resultado. In: "Vinte Centavos: A Luta Contra o Aumento", 2013 [http://www.cartacapital.com.br/sociedade/os-protestos-de-junho-entre-oprocesso-e-o-resultado-7745.html - acesso em janeiro de 2015].

PARREIRAS, Carolina. Internet e mercado erótico: notas etnográficas sobre x-sites. V ENEC - Encontro Nacional de Estudos do Consumo, 2010 [http://estudosdoconsumo.com.br/artigosdoenec/7.1.3-Parreiras Internet_e_mercado_erotico.pdf - acesso fevereiro 2015].

PISCITELLI, Adriana. Transnational Sisterhood? Brazilian Feminisms Facing Prostitution. Latin American Policy,vol. 5, Issue 2,December 2014, pp.221-235.

- Intersecionalidades, categorias de articulação e experiências de migrantes brasileiras. Sociedade e Cultura - Revista de Pesquisas e Debates Universidade Federal de Goiânia, vol.11, nº 2, 2008, pp.263-274

Plant, Sadie. Ceros+Unos. Barcelona: Ediciones Destino, 1998.

PRADO, Juliana do. Fortalecimento do masculino e redes de sociabilidade nos usos terapêuticos das mídias digitais. Seminário Internacional Fazendo Gênero 10 (Anais Eletrônicos), Florianópolis, 2013 [http://www.fazendogenero.ufsc.br/10/resources/anais/20/1385569023 _ARQUIVO_JulianadoPrado.pdf - acesso em janeiro de 2015]. 
PRECIADO, Beatriz. Después del Feminismo: Mujeres en los Márgenes. 13 de Enero de 2007. [http://webs.uvigo.es/pmayobre/textos/varios/despues_del_feminismo. pdf - acesso em janeiro de 2015].

SHAH, N. PlayBlog: "Pornography, performance and cyberspace". Cutup.com Magazine, vol.2.5, article 42, Holanda, 2005. [http://www.cutup.com/news/detail.php?sid $=413$ - acesso em janeiro de 2015].

TAVARES, Aline. A organização da zona: notas etnográficas sobre as relações de poder na zona de prostituição de Campinas - Jardim Itatinga. Dissertação de Mestrado em Antropologia Social, Campinas/IFCH/UNICAMP, 2014.

TORET, Javier et. alii. Tecnopolítica: la potencia de las multitudes conectadas. El sistema-red15M y el nuevo paradigma de la política distribuida, 2013 [http://in3wps.uoc.edu/index.php/in3-workingpaper-series/article/view/1878 - acesso em fevereiro de 2015].

VIANNA, Adriana. Atos, sujeitos e enunciados dissonantes: algumas notas sobre a construção dos direitos sexuais. In: MISKOLCI, Richard; Pelúcio, Larissa. (orgs.) Discursos fora da ordem: sexualidades, saberes e direitos. São Paulo, Annablume, 2012, pp. 227-244.

VIANNA, Adriana; CORRÊA, Sonia. Teoria e práxis em gênero e sexualidade: Trajetos, ganhos, perdas, limites... pontos cegos. Anais do VII Seminário Fazendo Gênero, 2006 [http://www.fazendogenero.ufsc.br/7/artigos/S/Sonia_Correa_52.pdf acesso em fevereiro de 2015].

ZAFRA, Remedios. Arte, Feminismo y Tecnologia. Reflexión sobre formas criativas y formas de domesticación. Quaderns de Psicologia,vol.16, n.1, 2014 [http://www.quadernsdepsicologia.cat/article/view/v16-n1zafra - acesso em janeiro de 2015].

. (H)adas: mujeres que crean, programan, prosumen, teclean. Madrid:Editorial Paginas de Espuma, 2013.

. Um cuarto próprio conectado: feminismo y creación desde la esfera público-privada online. Investigación Feminista, $\mathrm{n}^{\circ}$ 22, 2011 [http:/www.raco.cat/index.php/Asparkia/article/viewFile/257292/344383].

.Un cuarto própio conectado: (ciber) espacio y (auto) gestión del yo. Madrid, Fórcola Ediciones, 2010. 